\title{
Gambaran Terhadap Proses Perencanaan Keperawatan Dalam Mengimplementasikan Asuhan Keperawatan
}

\author{
Selly Febi Margaretha Panggabean \\ sellyfebi2601@gmail.com
}

\section{LATAR BELAKANG}

Proses keperawatan adalah suatu metode ilmiah yang sistematis dan terorganisir dalam memberikan asuhan keperawatan pada pasien yang berfokus pada respon individu terhadap gangguan kesehatan yang dialami (Manurung, 2011). Selama melaksanakan proses keperawatan, perawat menggunakan dasar pengetahuan yang komprehensif untuk mengkaji status kesehatan klien, membuat penilaian yang bijaksana dan mendiagnosa, mengidentifikasi hasil akhir kesehatan klien dan merencanakan, menerapkan dan mengevaluasi tindakan keperawatan yang tepat guna mencapai hasil akhir tersebut (Dermawan, 2012). Proses keperawatan dalam asuhan keperawatan juga berfungsi untuk memberikan kemampuan kepada perawat dalam memberi asuhan keperawatan kepada klien termasuk dalam sebuah pemecahan masalah yang akan dihadapi. Komponen proses keperawatan terdiri 5 komponen meliputi; pengkajian, diagnosa, perencanaan, implementasi, dan evaluasi. Semua tahapan dalam komponen proses keperawatan ini penting untuk diperhatikan dan juga dilakukan dengan baik oleh tenaga medis khususnya pada perawat. Salah satunya ialah pada tahapan perencanaan keperawatan atau juga disebut dengan intervensi keperawatan.

Perencanaan keperawatan adalah bagian dari fase pengorganisasian dalam proses keperawatan sebagai pedoman untuk mengarahkan tindakan keperawatan dalam usaha membantu, meringankan, memecahkan masalah atau untuk memenuhi kebutuhan pasien (Setiadi, 2012). Tahap perencanaan keperawatan merupakan tindakan menetapkan apa yang harus dilakukan untuk membantu sasaran dalam upaya promotif, preventif, kuratif, dan rehabilitatif. Langkah pertama dalam tahap perencanaan adalah menetapkan tujuan dan sasaran kegiatan 
untuk mengatasi masalah yang telah ditetapkan sesuai dengan diagnosis keperawatan. Diagnosis keperawatan merupakan penilaian perawat berdasarkan respon pasien secara holistik (bio-psikososio-spiritual) terhadap penyakit atau gangguan kesehatan yang dialaminya. Maka, diagnosis keperawatan merupakan kunci perawat dalam membuat rencana asuhan kesehatan yang diberikan pada pasien yang akan dikelola. Selanjutnya, dalam menentukan tahap berikutnya, yaitu rencana pelaksanaan kegiatan maka ada dua faktor yang mempengaruhi dan dipertimbangkan dalam menyusun rencana tersebut yaitu sifat masalah dan sumber atau potensi masyarakat seperti dana, sarana, dan tenaga yang tersedia.

Dalam proses perencanaan keperawatan yang baik mencerminkan kualitas perawatan dan membuktikan pertanggungjawaban setiap anggota tim perawatan dalam memberikan asuhan keperawatan pada klien. Maka, peran perawat sangat penting dalam pelaksanaan perencanaan keperawatan guna untuk di implementasikan kepada klien. Oleh karena itu, tim perawatan harus mengetahui keadaan status kesehatan klien dengan melakukan langkah - langkah dalam perencanaan keperawatan. Adapun langkah - langkah perencanaan keperawatan menurut Manurung (2011) yaitu; menentukan prioritas masalah, menuliskan tujuan dan kriteria hasil, serta memilih rencana tindakan atau intervensi keperawatan. Dengan hal ini, maka tim perawatan harus mengetahui tujuan serta langkah - langkah dalam melakukan perencanaan atau intervensi keperawatan untuk menilai kualitas pelayanan kesehatan serta menjadi salah satu faktor penentu dalam citra institusi pelayanan di mata masyarakat.

\section{METODE}

Dalam kajian ini, metode yang digunakan adalah literature review, yaitu dengan cara membaca, menganalisis, dan mengambil kesimpulan dalam sebuah sumber kajian (literature review) yang berkaitan dengan materi pembelajaran tentang gambaran terhadap proses perencanaan keperawatan dalam mengimplementasikan asuhan keperawatan. Adapun tinjauan literature review yang digunakan yaitu kajian jurnal online, textbook, e- book, dan sumber kajian (literature review) lainnya yang berkaitan dengan judul materi pembelajaran tersebut. Selanjutnya data yang telah dibaca, kemudian dianalisis dan disimpulkan dapat digunakan sebagai bahan pengambilan keputusan dalam menanggulangi permasalahan. Dengan 
menggunakan jurnal dan referensi yang digunakan pada literature review ini dengan tahun terbit paling lama tahun 2012, dengan jumlah minimal 10 referensi literature.

\section{HASIL}

Berdasarkan hasil yang dapat dianalisis dari berbagai sumber kajian (literature review), didapatkan bahwa adanya aspek- aspek intervensi keperawatan yang direncanakan yakni; mengatasi etiologi diagnosis keperawatan, kemudian konkrit/ aktual/ nyata/ jelas, serta intervensi keperawatan yang dilakukan dalam pendokumentasian yaitu; (apa yang dilakukan, bagaimana, seberapa sering, siapa yang melakukannya). Kemudian didapati juga hasil yang telah dianalisis dari sumber kajian (literature review), yang menunjukkan bahwa adanya hubungan dan pengaruh terhadap pelaksanaan komponen asuhan keperawatan yang berkaitan dengan pendidikan maupun pengetahuan yang dimiliki oleh perawat. Adapun hasil penelitian yang dapat disimpulkan dari sumber kajian (literature review), yang telah dikaji, dibaca dan dianalisis terkait dengan aspek dan hubungan dalam perencanaan keperawatan diatas yaitu:

Dalam Jurnal, Aplikasi Standar Proses Keperawatan: Diagnosis, Outcome, Dan Intervensi Pada Asuhan Keperawatan. Jurnal Keperawatan Silampari Volume 3, Nomor 2, Juni 2020. Berdasarkan hasil penelitian yang dapat disimpulkan dari jurnal tersebut, didapati bahwa intervensi yang telah direncanakan sudah mencakup aspek tindakan observasi, mandiri, dan kolaborasi. Namun, belum semua berorientasi pada tujuan dan kriteria hasil. Selain itu, spesifikasi intervensi mengenai bagaimana, seberapa sering, dan siapa yang melakukan tindakan belum didukung oleh sistem informasi yang digunakan karena perawat tidak dapat menginput dokumentasi pada tahapan intervensi keperawatan dalam spesifikasi tersebut.

Kemudian, dalam Jurnal Gambaran Tingkat Pengetahuan Perawat Dalam Penerapan Standar Asuhan Keperawatan Diruangan Rawat Inap Interna RSUD Datoe Bhinangkang. EJournal Keperawatan (e- Kp). Vol.3,No.3 Agustus 2015. Berdasarkan hasil penelitian yang dapat disimpulkan dari jurnal tersebut, didapati bahwa adanya faktor- faktor hubungan yang dapat mempengaruhi dalam perencanaan keperawatan yakni; jenis kelamin, umur, tingkat pendidikan, status pekerjaan, lama bekerja, jabatan, serta tingkat pengetahuan. Kemudian didapati juga bahwa kualitas dalam melakukan perencanaan keperawatan lebih diutamakan pada faktor tingkat 
pengetahuan dan faktor tingkat pendidikan bagi seorang perawat. Dimana hal ini sangat mempengaruhi bagi perawat dalam keberhasilan melakukan proses perencanaan keperawatan. Dalam hal hasil, jika perawat memiliki tingkat pendidikan serta tingkat pengetahuan yang baik dan memiliki masa bekerja yang relatif lama, maka akan tercapainya keberhasilan dalam melakukan intervensi atau perencanaan keperawatan serta juga dapat meningkatkan mutu kualitas dalam pelayanan kesehatan.

\section{PEMBAHASAN}

Perencanaan merupakan tahap selanjutnya setelah pengkajian dan penentuan diagnosa keperawatan. Perencanaan juga merupakan petunjuk tertulis yang menggambarkan secara tepat mengenai rencana tindakan yang dilakukan terhadap pasien sesuai dengan tingkat kebutuhan berdasarkan diagnosa keperawatan yang muncul. Untuk itu rencana tindakan yang baik tentunya harus berdasarkan pada diagnosa keperawatan yang telah dirumuskan (Hartati,Handoyo, Anis, 2010). Penentuan prioritas masalah juga terdapat dalam tahap perencanaan ini. Penentuan prioritas dilakukan karena tidak semua masalah dapat diatasi secara bersamaan. Di dalam perencanaan juga perlu diperhatikan perumusan tujuan yang hendak dicapai dari intervensi yang telah diberikan. Dengan adanya tujuan ini akan mempermudah perawat di dalam melakukan evaluasi. Di dalam proses perencanaan ini, juga terdapat keterlibatan pasien dan keluarga juga harus diikutsertakan di dalam penetapan rencana keperawatan. Karena antara perawat, pasien dan keluarga harus bekerjasama di dalam intervensi agar dapat mencapai tujuan dengan baik. Begitu juga kerjasama dengan tim kesehatan lain juga sangat dibutuhkan untuk mengatasi masalah medis secara kolaborasi.

Intervensi keperawatan dibuat untuk mencapai tujuan dan kriteria hasil yang diharapkan guna mengatasi etiologi dan menyelesaikan masalah keperawatan. Intervensi dibuat secara spesifik dan operasional yang terdiri dari aktivitas apa yang akan dilakukan, bagaimana, seberapa sering, dan lebih baik lagi jika teridentifikasi siapa yang melakukan. Prinsip tersebut perlu dilakukan supaya tiap perawat yang melihat perencanaan keperawatan mudah untuk melakukannya atau mengaplikasikan rencana tersebut. Setelah tindakan telah dilakukan, tiap intervensi dievaluasi berdasarkan respon pasien terhadap tiap tindakan yang telah 
diimplementasikan dan mengacu atau berorientasi pada kriteria hasil yang telah ditetapkan (Abdelkader, Othman, 2017). Adapun terdapat dari sumber kajian (literature review) yang telah dianalisis, didapatkan bahwa ada prinsip lain yang juga menjadi dasar proses intervensiimplementasi adalah "lakukan apa yang ditulis" (intervensi-implementasi) dan "tulis apa yang dilakukan” (implementasi-dokumentasi). Kedua prinsip tersebut merupakan dasar pendokumentasian/pencatatan dan pelaporan asuhan keperawatan. Prinsip tersebut akan mempertahankan aspek legal dan etik keperawatan serta dapat melindungi perawat dari segi atau aspek hukum dan etik.

Di dalam merencanakan sebuah intervensi keperawatan, perawat harus memperhatikan langkah - langkah sebelum melakukan pelaksanaan tindakan dalam merumuskan sebuah intervensi keperawatan.

Adapun langkah - langkah perencanaan keperawatan menurut Manurung (2011) adalah sebagai berikut:

\section{Menentukan Prioritas Masalah}

Prioritas keperawatan adalah penyusunan diagnosa keperawatan atau masalah pasien dengan menggunakan tingkat kedaruratan atau kepentingan untuk memperoleh tahapan intervensi keperawatan yang dibutuhkan. Dalam menentukan perencanaan perlu disusun suatu sistematis untuk menentukan diagnosis yang akan pertama kali di intervensi. Saat menentukan prioritas diagnosa keperawatan digunakan standar prioritas kebutuhan dari Maslow, sebagai berikut :

- Prioritas 1 : masalah yang berhubungan dengan kebutuhan fisiologis seperti respirasi, sirkulasi, nutrisi, hidrasi, eliminasi, suhu dan kesenjangan fisik.

- Prioritas 2 : masalah yang berpengaruh pada keselamatan dan keamanan.

- Prioritas 3: masalah yang berpengaruh terhadap cinta dan rasa memiliki.

- Prioritas 4 : masalah yang berpengaruh pada rasa harga diri.

- Prioritas 5 ; masalah yang berpengaruh pada kemampuan mencapai sasaran pribadi atau aktualisasi diri. 
Maka, pengurutan prioritas diatas akan dipengaruhi oleh faktor - faktor persepsi pasien terhadap prioritas, untuk itu seorang perawat harus menanyakan kepada pasien tentang apa yang dirasakannya dan ini merupakan hal yang penting bagi perawat dalam melakukan tindakan intervensi keperawatan

\section{Menuliskan Tujuan Dan Kriteria Hasil}

Kriteria hasil (outcome) adalah untuk diagnosis keperawatan mewakili status kesehatan klien dapat diubah atau dipertahankan melalui rencana asuhan keperawatan yang mandiri, sehingga dapat dibedakan antara diagnosis keperawatan dan masalah kolaboratif. Tujuan perawatan adalah hasil yang diinginkan dari asuhan keperawatan yang diharapkan dapat dicapai bersama pasien serta direncanakan untuk mengurangi masalah yang telah diidentifikasi dalam diagnosis keperawatan (Manurung, 2011). Kriteria hasil mempunyai ciriciri menurut Dermawan (2012) yaitu setiap kriteria hasil berhubungan dengan tujuan yang telah ditetapkan, hasil yang ditetapkan dalam kriteria hasil, memungkinkan untuk dicapai, setiap kriteria hasil adalah pernyataan satu hal yang spesifik, kriteria harus sekonkrit mungkin untuk memudahkan pengukuran, kriteria cukup besar atau dapat diukur, kriteria menggunakan kata-kata positif bukan menggunakan kata negatif. Menurut Gordon (1994), komponen yang penting dalam kriteria hasil adalah apakah intervensi keperawatan dapat dicapai. Adapun pedoman penulisan kriteria hasil menurut Setiadi (2012) adalah berfokus pada pasien, singkat dan jelas, dapat diobservasi dan dapat diukur, ada batas waktu, serta ditentukan oleh perawat dan pasien.

\section{Memilih Rencana Tindakan atau Intervensi Keperawatan}

Adapun urutan dalam memilih rencana tindakan atau intervensi keperawatan yaitu :

1) Tindakan keperawatan harus aman bagi pasien.

2) Tindakan keperawatan harus sejalan dengan tindakanpengobatan.

3) Tindakan keperawatan harus didasari prinsip dan pengetahuan yang digabungkan dari pendidikan dan pengalaman sebelumnya. 
4) Tulis sekumpulan tindakan keperawatan untuk mencapai setiap tujuan.

5) Pilih satu kumpulan tindakan keperawatan yang kiranya cocok dengan sikap yang disebutkan dalam pernyataan tujuan.

6) Tindakan keperawatan harus realistis.

7) Tindakan keperawatan harus penting bagi peningkatan kesehatan pasien dan sejalan dengan tujuan serta nilai perseorangan pasien.

8) Gunakan pasien sebagai sumber-sumber dalam memilih tindakan keperawatan.

9) Tulis tindakan keperawatan secara berurutan

Dalam proses perencanaan keperawatan, seorang perawat harus mampu melakukan perencanaan keperawatan, menentukan tujuan, dan memilih intervensi yang baik untuk mencapai tujuan keperawatan. Hal ini dikarenakan oleh ilmu dan keterampilan yang dimiliki seorang perawat dalam masa pendidikan dan menjadikan hal ini sebagai landasan dalam melaksanakan perencanaan keperawatan . Hal ini didukung oleh Siagian (2002), bahwa semakin tinggi tingkat pendidikan seseorang, maka akan semakin tinggi pengetahuannya.

Selanjutnya pada tahap evaluasi merupakan tahap terakhir dari proses keperawatan berupa perbandingan yang sistematis dan terencana dari hasil-hasil yang diamati dengan tujuan dan kriteria hasil yang dibuat pada tahap perencanaan. Pada tahap evaluasi ini, terdapat adanya hubungan yang signifikan setelah melakukan tahapan intervensi atau perencanaan serta implementasi yang telah ditetapkan dalam proses keperawatan.

Pada kegiatan evaluasi ini, dikaitkan dengan hasil - hasil yang diperoleh setelah melakukan tindakan dalam proses keperawatan. Adapun didapati bahwa pada tahap evaluasi yang baik ini juga dapat dipengaruhi oleh tingkat pendidikan serta pengetahuan, dimana hubungan tingkat pendidikan dan pengetahuan masih dikategorikan yang paling utama dalam melakukan sebuah tindakan perencanaan proses keperawatan. Maka, tingkat pendidikan serta pengetahuan yang dimiliki seorang perawat dapat menunjang dan 
menilai pada kinerja seorang perawat dalam menerapkan tindakan yang baik dalam proses keperawatan.

\section{PENUTUP}

Menurut Kozier et al. (1995) perencanaan adalah sesuatu yang telah dipertimbangkan secara mendalam, tahap yang sistematis dari proses keperawatan meliputi kegiatan pembuatan keputusan dan pemecahan masalah. Dalam perencanaan keperawatan, perawat harus menetapkan tindakan keperawatan berdasarkan hasil pengumpulan data dan rumusan diagnosa keperawatan yang merupakan petunjuk dalam membuat tujuan dan asuhan keperawatan untuk mencegah, menurunkan, atau mengeliminasi masalah kesehatan klien. Adapun strategi intervensi keperawatan yang berhubungan dengan diagnosa keperawatan spesifik yang harus ditetapkan perawat untuk mencapai tujuan perawatan klien dan kriteria hasil. Intervensi keperawatan yang spesifik harus berfokus dalam mengeliminasi atau menurunkan etiologi (penyebab) dari diagnosa keperawatan, dan sesuai dengan pernyataan tujuan serta kriteria hasil.

Pada tindakan perencanaan keperawatan, perawat juga harus tepat menggambarkan secara tepat mengenai rencana tindakan yang dilakukan terhadap pasien sesuai dengan tingkat kebutuhan berdasarkan diagnosa keperawatan yang muncul. Disamping itu jika perawat melakukan semua tindakan proses perencanaan keperawatan dengan baik, maka akan tercapainya peningkatan asuhan keperawatan serta dapat meningkatkan akreditasi dalam mutu pelayanan kesehatan. 


\section{DAFTAR PUSTAKA}

Achmadi, L. D., Pondaag, L., \& Babakal, A. (2015). Gambaran Tingkat Pengetahuan Perawat dalam Penerapan Standar Asuhan Keperawatan di Ruangan Rawat Inap Interna RSUD Datoe Bhinangkang. Jurnal Keperawatan. 3 (3): 1-3

Astar, Fatmawati, dkk. (2018). PENGARUH PELAYANAN ASUHAN KEPERAWATAN TERHADAP KEPUASAN PASIEN DI PUSKESMAS TAKALALA KABUPATEN SOPPENG. Journal stieamkop MIRAI : JOURNAL OF MANAGEMENT. 1 ( 2) : 33-57.

Budiono \& Sumirah,B,P.(2016). Konsep Dasar Keperawatan (Ed 2). Jakarta. Bumi Medika.

Butar- Butar, J., \& Simamora, R. H. (2016). Hubungan Mutu Pelayanan Keperawatan dengan Tingkat Kepuasan Pasien Rawat Inap di RSUD Pandan Kabupaten Tapanuli Tengah. Jurnal Ners Indonesia, 6(1), 50-63.

Iqbal, M. B., Hendro, dkk. (2017). Pengaruh Manajemen Model Asuhan Keperawatan Profesional Tim Terhadap Kualitas Pelayanan Keperawatan Di Bangsal Pria Rsud Datoe Binangkang Kabupaten Bolaang Mongondow . Manado. Vol (5) No. 2. e-Jurnal Keperawatan (e-Kp) Universitas Sam Ratulangi.

Nurlina, dkk. (2013). Faktor-Faktor Yang Berhubungan dengan Penerapan Standar Asuhan Keperawatan Di Ruang Rawat Inap RSUD Labuang Baju Makassar. Journal Univeristas Negri Makassar. 7 ( 4 )

Putra Aryata P.I. (2012). Analisis Penerapan Standar Asuhan Keperawatan di Ruang Rawat Inap Rumah Sakit Umum Provinsi Sulawesi Tenggara. Tesis Universitas Gajah Mada. Yogyakarta. Universitas Gajah Mada.

Rosdahl, B. C. \& Kowalski, T. M. (2014). Buku Ajar Keperawatan Dasar. Ed.10.Vol 1. Jakarta: EGC.

Simamora, R. H. (2005). Hubungan Persepsi Perawat Pelaksana Terhadap Penerapan Fungsi Pengorganisasian Yang Dilakukan Oleh Kepala Ruangan Dengan Kinerjanya Diruang 
Rawat Inap RSUD Koja Jakarta Utara (Doctoral dissertation, Tesis FIK UI, Tidak dipublikasikan).

Siswanto, L.M. Harmain, dkk. (2013). Faktor - Faktor yang Berhubungan dengan Kelengkapan Pendokumentasian Asuhan Keperawatan. Jurnal Keperawatan Indonesia.16(2): 77-84

Srimiyati, Koerniawan. D, Daeli, N.E. (2020).Aplikasi Standar Proses Keperawatan: Diagnosis, Outcome, Dan Intervensi Pada Asuhan Keperawatan. Jurnal Keperawatan Silampari Volume 3, Nomor 2

Wirdah Husnul, Yusuf Muhmmad. (2016). Penerapan Asuhan Keperawatan oleh Perawat Pelaksana di Rumah Sakit Banda Aceh. Jurnal Ilmu Keperawatan unsyiah. 1 (1) : 1-7 